Check for updates

Cite this: J. Mater. Chem. A, 2020, 8 , 15157

Received 11th May 2020

Accepted 20th July 2020

DOI: $10.1039 / d 0 t a 04866$

rsc.li/materials-a

\section{Ionic conductive and photocatalytic properties of cementitious materials: calcium silicate hydrate and calcium aluminoferrite}

\author{
Masahiro Nagao, (D) a Kazuyo Kobayashi, ${ }^{a}$ Yongcheng Jin, (D) ${ }^{\mathrm{b}}$ Ippei Maruyama (D) ac \\ and Takashi Hibino iD *a
}

\begin{abstract}
Few studies have reported the ionic conductive and photoactive properties of cementitious materials, owing to the compositional and structural variations of cement paste. The present report focuses on calcium silicate hydrate $(\mathrm{C}-\mathrm{S}-\mathrm{H})$ and tetracalcium aluminoferrite $\left(\mathrm{C}_{4} \mathrm{AF}\right)$, prepared individually from pure constituent elements. $\mathrm{C}-\mathrm{S}-\mathrm{H}$ is an ionic conductor with a conductivity ranging from $10^{-4}$ to $10^{-3} \mathrm{~S} \mathrm{~cm}^{-1}$ in humidified air at temperatures between 60 and $100{ }^{\circ} \mathrm{C}$. The hydroxide ions present in the mesopores of $\mathrm{C}-\mathrm{S}-\mathrm{H}$ as basic $\mathrm{O}-\mathrm{H}$ groups were determined to be the major charge carriers, and the faradaic efficiency for the water oxidation reaction was estimated to be approximately $100 \%$. $\mathrm{C}_{4} \mathrm{AF}$ is a mixed ionic n-type electronic conductor, particularly at high oxygen partial pressures. The conductivity of this compound was several times lower than that of $\mathrm{C}-\mathrm{S}-\mathrm{H}$ under the same humidity and temperature conditions, not only because of the bulk resistance but also the grain boundary resistance. $\mathrm{C}_{4} \mathrm{AF}$ and the hydrates exhibited photovoltaic and photocatalytic responses for water splitting and methylene blue degradation, respectively. These results indicate the important contribution of $\mathrm{C}-\mathrm{S}-\mathrm{H}$ and hydrated $\mathrm{C}_{4} \mathrm{AF}$ to the electrochemical and photochemical properties of cement paste.
\end{abstract}

\section{Introduction}

Advanced cementitious materials are being actively developed to enhance the performance ${ }^{1}$ and durability of concrete. ${ }^{2,3}$ Great attention is devoted to eco-cementitious materials that can reduce environmental impact and coexist with the environment. ${ }^{4-6}$ However, data on the electrochemical and photochemical properties of cement paste are lacking in the guidelines for the design and operation of these materials. Degradation of reinforced concrete is triggered by deterioration of the cement paste and corrosion of the steel beams and columns, which are mainly due to the carbonation of and salt damage to concrete induced by the external environment. ${ }^{7,8}$ However, the degradation mechanism related to the internal conditions of concrete is not well understood. Additionally, building finishing materials play a very important role in creating a comfortable indoor environment and keeping building exteriors clean, but these functionalities are conventionally achieved by coating the concrete surface with a photocatalyst. ${ }^{9,10}$

\footnotetext{
${ }^{a}$ Graduate School of Environmental Studies, Nagoya University, Nagoya 464-8601, Japan. E-mail: hibino@urban.env.nagoya-u.ac.jp

${ }^{b}$ School of Materials Science and Engineering, Ocean University of China, Qingdao 266100, China

'Graduate School of Engineering, The University of Tokyo, Tokyo 113-8656, Japan
}

It has been demonstrated that the ionic conduction in a hardened cement paste is driven by the humidification of a thin cement-based membrane. ${ }^{\mathbf{1 1}}$ When the cement paste was moistened, the electrical resistance decreased by two orders of magnitude, the extent of which became more significant as the temperature increased. However, since there are many constituent cations and anions in cement paste, it cannot be determined which ions conduct charge carriers in the solid. Calcium silicate hydrate (C-S-H), the main hydration product of Portland cement, as well as sodium and potassium hydroxides $(\mathrm{NaOH}$ and $\mathrm{KOH}$ ), are believed to be ion-conductive materials. However, calcium hydroxide $\left(\mathrm{Ca}(\mathrm{OH})_{2}\right)$ is a minor ionic conductor, because of its low solubility product. If the ionic conductivity of C-S-H is comparable to those of alkali metal hydroxides, then the $\mathrm{pH}$ of the solution in the pores of the cement paste would be determined not only by the amounts of alkali metal hydroxides but also the amount of $\mathrm{C}-\mathrm{S}-\mathrm{H}$, thus affecting the corrosion behavior of steel.

Iron-based oxides such as $\mathrm{Fe}_{3} \mathrm{O}_{4}, \mathrm{CuFe}_{2} \mathrm{O}_{4}$, and $\mathrm{ZnFe}_{2} \mathrm{O}_{4}$ have been studied as photocatalysts. ${ }^{\mathbf{1 2 , 1 3}}$ Unlike the commonly known titanium dioxide $\left(\mathrm{TiO}_{2}\right)$, these metal oxides show visible-lightinduced catalytic activity, which enables the use of white LED lamps as the light source for various photoinduced reactions. Hirabayashi et al. reported the photocatalytic activity of brownmillerite-type $\mathrm{Ca}_{2} \mathrm{Fe}_{2} \mathrm{O}_{5}$, which is similar in structure and composition to tetracalcium aluminoferrite $\left((\mathrm{CaO})_{4} \cdot \mathrm{Al}_{2} \mathrm{O}_{3} \cdot \mathrm{Fe}_{2}\right.$ $\left.\mathrm{O}_{3} ; \mathrm{C}_{4} \mathrm{AF}\right)$, one of the main components of Portland cement. ${ }^{\mathbf{1 4}}$ 
$\mathrm{C}_{4} \mathrm{AF}$ undergoes hydration to form ettringite (katoite) in the presence (absence) of gypsum $\left(\mathrm{CaSO}_{4}\right) \cdot{ }^{15,16}$ It is also reported that $\mathrm{C}_{4} \mathrm{AF}$ exists as Fe-siliceous hydrogarnet during hydration in the coexistence of silicate. ${ }^{17,18}$ It is meaningful to investigate the photochemical properties of these products; however, we consider it as future work, because the crystalline structure and solid solution state of the hydration products cannot be precisely controlled in the synthesis, thus making it difficult to obtain pure and reproducible material at this moment. (Even if a certain product is obtained, it may not be accepted as a satisfactory representative of various products of $\mathrm{C}_{4} \mathrm{AF}$.) According to the literature, the degree of hydration of $\mathrm{C}_{4} \mathrm{AF}$ remains in the 0.6-0.8 range 1 year after the start of hydration. ${ }^{19}$ Moreover, as will be discussed later, a $\mathrm{C}_{4} \mathrm{AF}$-rich cement clinker can be used to enhance the photocatalytic activity of the cement paste, which would further increase the amount of unreacted $\mathrm{C}_{4} \mathrm{AF}$ in the concrete. For these reasons, an easily synthesizable and highly pure $\mathrm{C}_{4} \mathrm{AF}$ was used as a research target in this study.

The goal of this study was to investigate the electro- and photo-chemical properties of cementitious materials. C-S-H and $\mathrm{C}_{4} \mathrm{AF}$ were prepared from pure constituent elements. The experimental conditions were adjusted by controlling the temperature and humidity of the sample during the measurements. In the electrochemical measurements, the alternating current (AC) conductivity was compared with the direct current (DC) conductivity to separate the electrical resistance components. Various galvanic cells were constructed to inspect the electrochemical behavior of the conductive ions in the solid. In the photochemical measurements, photovoltaic water splitting and photocatalytic degradation of methylene blue (MB) were performed under visible light irradiation. The relationships between the function and structure of C-S-H and $\mathrm{C}_{4} \mathrm{AF}$ were discussed.

\section{Experimental}

\section{Synthesis of C-S-H and $\mathrm{C}_{4} \mathrm{AF}$}

$\mathrm{Ca}(\mathrm{OH})_{2}$ (Kanto Chemical, 96\%) and fumed silica (Evonik, Aerosil 200) were used for the synthesis of C-S-H, and $\mathrm{Ca}(\mathrm{CO})_{3}$ (Kanto Chemical, 99.5\%), $\mathrm{Al}_{2} \mathrm{O}_{3}$ (Showa Denko, AL-160), and $\mathrm{Fe}_{2} \mathrm{O}_{3}$ (Kanto Chemical, 99\%) were used for the synthesis of $\mathrm{C}_{4} \mathrm{AF}$. These reagents were all used without further purification. $\mathrm{Ca}(\mathrm{OH})_{2}$ and fumed silica powders were mixed at a Ca/Si molar ratio of 1.4 in deionized water and then stirred in a sealed container at $70{ }^{\circ} \mathrm{C}$ for 7 days. The product was filtered in an argon (Ar) glove box to prevent carbonation of the product. The filtrate was immediately transferred to a vacuum dryer. The appropriate amounts of $\mathrm{Ca}(\mathrm{CO})_{3}, \mathrm{Al}_{2} \mathrm{O}_{3}$, and $\mathrm{Fe}_{2} \mathrm{O}_{3}$ powders were mixed with a mortar and pestle. The mixture was pressed into pellets and then calcined in an alumina crucible at $1350{ }^{\circ} \mathrm{C}$ for $10 \mathrm{~h}$. The product was ground into a powder using a stirred ball mill. To increase the specific surface of $\mathrm{C}_{4} \mathrm{AF}$, this sample was optionally treated using a planetary ball mill at a rotation speed of $150 \mathrm{rpm}$. The C-S-H and $\mathrm{C}_{4} \mathrm{AF}$ membranes used for, respectively, electro- and photo-chemical measurements were prepared by binding $1.00 \mathrm{~g}$ of the powder with $0.07 \mathrm{~g}$ of polytetrafluoroethylene (PTFE) and then cold-rolling it to a thickness of $0.5 \mathrm{~mm}$ and a diameter of $c a .17 \mathrm{~mm}$.

\section{Characterization}

All measurements were conducted on the synthesized C-S-H and $\mathrm{C}_{4} \mathrm{AF}$ powders. X-ray powder diffraction (XRD) patterns were collected on a MiniFlex II (Rigaku) using $\mathrm{CuK} \alpha$ radiation over a $2 \theta$ range from $10^{\circ}$ to $60^{\circ}$. Transmission electron microscopy (TEM) images were obtained using a JEM-2100Plus (JEOL) at an accelerating voltage of $200 \mathrm{kV}$ with a beam current of $92 \mu \mathrm{A}$. Nitrogen $\left(\mathrm{N}_{2}\right)$ and krypton $(\mathrm{Kr})$ isotherms were recorded at a relative pressure of 0 to 0.98 for $\mathrm{N}_{2}$ and 0 to 0.68 for $\mathrm{Kr}$ at liquid $\mathrm{N}_{2}$ temperatures using a BELSORP 18PLUS-HT (Nihon Bell). The samples were degassed at $150{ }^{\circ} \mathrm{C}$ for $5 \mathrm{~h}$ before measurements. The pore size distribution was calculated using the grand canonical Monte Carlo (GCMC) technique. The Brunauer-Emmett-Teller (BET) method was employed to determine the specific surface areas from multi-point $\mathrm{N}_{2}$ adsorption data obtained by using an adsorption/desorption apparatus in the case of C-S-H and one-point desorption data obtained by using a conventional flow apparatus equipped with a thermal conductivity detector (TCD) in the case of $\mathrm{C}_{4} \mathrm{AF}$. Simultaneous thermogravimetry (TG) and differential thermal analysis (DTA) were performed using a DTG-60 (Shimadzu). The samples were heated in flowing air from room temperature to $900{ }^{\circ} \mathrm{C}$ at a rate of $10^{\circ} \mathrm{C} \mathrm{min}^{-1}$. Infrared spectra were measured using a Fourier transform-IR (FTIR) system (FT/IR-460 JASCO). Spectral analysis was performed in the $4000-400 \mathrm{~cm}^{-1}$ range with a resolution of $1 \mathrm{~cm}^{-1}$. The temperature-programmed desorption (TPD) technique using $\mathrm{CO}_{2}$ as probe molecule was employed to determine the basicity of C-S-H and $\mathrm{C}_{4} \mathrm{AF} .0 .2 \mathrm{~g}$ of the powder were placed at the center of a quartz tube, and $\mathrm{CO}_{2}$ was adsorbed by supplying $100 \% \mathrm{CO}_{2}$ for $1 \mathrm{~h}$ at room temperature. After purging with $\mathrm{Ar}$, the furnace temperature was raised from room temperature to $900{ }^{\circ} \mathrm{C}$ at a rate of $10{ }^{\circ} \mathrm{C} \mathrm{min}^{-1}$. The concentration of $\mathrm{CO}_{2}(\mathrm{~m} / \mathrm{z}=44)$ in the outlet gas from the quartz tube was monitored using a mass spectrometer (ThermoStar, Pfeiffer Vacuum).

\section{Electrochemical measurements}

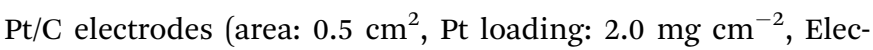
troChem) were attached to both surfaces of the membrane sample and then fixed in graphite holders. The cell was humidified by simultaneously supplying deionized water ( 0.13 $\left.\mathrm{mL} \min ^{-1}\right)$ and high-purity air $\left(10 \mathrm{~mL} \mathrm{~min}^{-1}\right.$, Taiyo Nippon Sanso) to the bottom holder. The cell temperature was adjusted using a plate heater with a thermocouple. The DC resistance was measured by varying the current density from 2 to $10 \mathrm{~mA}$ $\mathrm{cm}^{-2}$. The current was interrupted for $0.0002 \mathrm{~s}$ at intervals of $0.002 \mathrm{~s}$ using a current pulse generator (Nikko Keisoku). The voltage signal from the cell was captured by a digital oscilloscope workstation (Nicolet). The AC impedance was measured by a potentiostat/galvanostat (Solartron Analytical 1280) and an impedance/gain-phase analyzer (Solartron Analytical 1260A) with an amplitude voltage of $60 \mathrm{mV}$ in the frequency range of 0.1 to $10^{6} \mathrm{~Hz}$. Impedance measurements were also performed at various partial pressures of oxygen $\left(P_{\mathrm{O}_{2}}\right)$, which were obtained by mixing oxygen $\left(\mathrm{O}_{2}\right)$ or hydrogen $\left(\mathrm{H}_{2}\right)$ with Ar. The $P_{\mathrm{O}_{2}}$ of the mixture was monitored using a zirconia $\mathrm{O}_{2}$ sensor. In water 
vapor concentration cells, an air - deionized water mixture and unhumidified air were fed to the bottom and top holders, respectively. In the oxygen gas concentration cell, i.e., the fuel cell, a mixture of $\mathrm{H}_{2}$ and deionized water and a mixture of air and deionized water were fed to the bottom and top holders, respectively. The voltage generated from the cell was recorded using an HE-104 electrometer (Hokuto Denko). Water vapor electrolysis was performed in flowing Ar by using the $\mathrm{Pt} / \mathrm{C}$ electrode on the top holder as the cathode. $\mathrm{H}_{2}(\mathrm{~m} / \mathrm{z}=2)$ generated from the cathode at a constant current density was detected using the mass spectrometer.

\section{Photochemical measurements}

A white LED lamp composed of 16 units (ODS-LS-16, OHM) was used as a visible light source. The average intensity of the lamp was $4.8 \mathrm{~W} \mathrm{~m}^{-2}$, which was measured using a light irradiance meter (T-10A, Konica Minolta). Water splitting was conducted by fabricating an $\mathrm{H}$-type glass-made reactor consisting of a $\mathrm{C}_{4} \mathrm{AF}$ membrane anode and a Pt plate cathode immersed in a $1 \mathrm{M}$ $\mathrm{NaOH}$ electrolyte solution. The anode surface was irradiated with the lamp at a distance of $c a .15 \mathrm{~cm}$ from the front. Cyclic voltammetry $(\mathrm{CV})$ profiles were collected between 0 and $+1.6 \mathrm{~V}$ at a scan rate of $10 \mathrm{mV} \mathrm{s}$. Then, impedance spectra were acquired in a manner similar to that used for the AC resistance measurements, except that a bias voltage of $+1 \mathrm{~V}$ was applied to the cell. Photocatalytic degradation of $\mathrm{MB}$ was conducted in a $100 \mathrm{~mL}$ Pyrex beaker that was irradiated from the top, with the lamp positioned $c a .15 \mathrm{~cm}$ above the beaker. A total of $0.1 \mathrm{~g}$ of the $\mathrm{C}_{4} \mathrm{AF}$ powder was dispersed in $10 \mathrm{~mL}$ of $10 \mathrm{ppm} \mathrm{MB}$ solution (Kanto Chemical), whose $\mathrm{pH}$ was maintained at 7.2 by adding a phosphate buffer solution (Nacalai Tesque). Absorption spectra of the solution were recorded using a UV-visible spectrophotometer (JASCO UV 360) with a quartz cell of $10 \mathrm{~mm}$ path length. The absorbance of MB was acquired between 200 and $800 \mathrm{~nm}$ (fixed $1 \mathrm{~nm}$ width) at specific irradiation time intervals.

\section{Results and discussion}

\section{Characterization of C-S-H and $\mathrm{C}_{4} \mathrm{AF}$}

An XRD pattern with no detectable $\mathrm{Ca}(\mathrm{OH})_{2}, \mathrm{CaCO}_{3}$, or $\mathrm{SiO}_{2}$ peaks was obtained for the C-S-H sample, as shown in Fig. 1a. The crystalline phase was identified as calcium silicate hydrate $\left(\mathrm{Ca}_{1.5} \mathrm{SiO}_{3.5} \cdot x \mathrm{H}_{2} \mathrm{O}\right.$; PDF 00-033-0306) on the basis of the three peaks at $2 \theta=29^{\circ}, 32^{\circ}$, and $50^{\circ} .^{20,21}$ However, this assignment may not be correct, because the preparation of $\mathrm{C}-\mathrm{S}-\mathrm{H}$ at a $\mathrm{Ca} / \mathrm{Si}$ molar ratio as high as 1.4 causes the formation of a Ca-rich phase (probably amorphous $\mathrm{Ca}(\mathrm{OH})_{2}$ or nanocrystalline portlandite), which results in a smaller $\mathrm{Ca} / \mathrm{Si}$ molar ratio in the case of C-S-H, as compared to that of the starting composition. ${ }^{22-25}$ Different morphologies are observed for $\mathrm{C}-\mathrm{S}-\mathrm{H}$ products in hardened Portland cements, depending on the composition and preparation conditions of C-S-H. ${ }^{24,26}$ The TEM image in Fig. 1b indicates that C-S-H had a plate- or sheet-like morphology, 50-100 $\mathrm{nm}$ in thickness and $400 \mathrm{~nm}$ in length. In addition, fine dark spots, assignable to Ca-rich phases, were seen on the surface of the C-S-H plates. These observations are
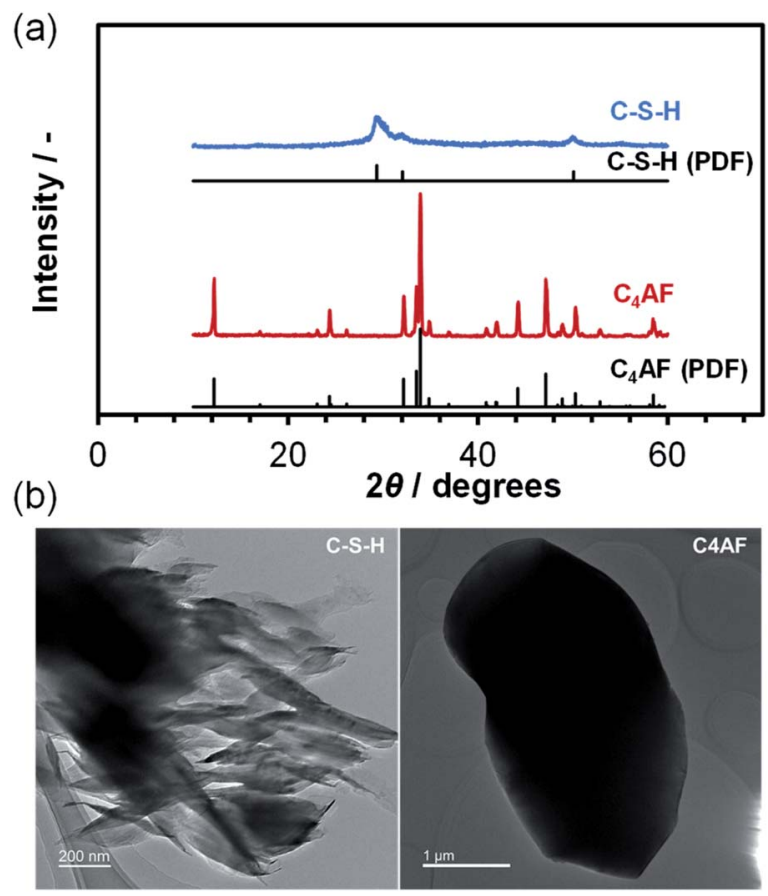

Fig. 1 (a) XRD patterns for $\mathrm{C}-\mathrm{S}-\mathrm{H}$ and $\mathrm{C}_{4} \mathrm{AF}$. The PDFs of $\mathrm{Ca}_{1.5^{-}}$ $\mathrm{SiO}_{3.5} \cdot x \mathrm{H}_{2} \mathrm{O}$ and $\mathrm{Ca}_{2} \mathrm{FeAlO}_{5}$ are included for reference. (b) TEM images of $\mathrm{C}-\mathrm{S}-\mathrm{H}$ and $\mathrm{C}_{4} \mathrm{AF}$.

consistent with the results reported by Richardson, who prepared $\mathrm{C}-\mathrm{S}-\mathrm{H}$ at a $\mathrm{Ca} / \mathrm{Si}$ molar ratio of $1.5 .^{27}$

Fig. 1a also shows the XRD pattern for the $\mathrm{C}_{4} \mathrm{AF}$ sample, which is indexed to brownmillerite $\left(\mathrm{Ca}_{2} \mathrm{FeAlO}_{5}\right.$; PDF 01-0710667), ${ }^{28}$ with an average crystallite size of $446 \AA$. This pattern is almost identical to that refined previously by Rietveld analysis, ${ }^{\mathbf{1 1}}$ where the octahedral and tetrahedral layers, occupied by $\mathrm{Fe}^{3+}$ and $\mathrm{Al}^{3+}$ ions, respectively, were alternately connected in the brownmillerite structure. It appears from the TEM image in Fig. $1 \mathrm{~b}$ that the $\mathrm{C}_{4} \mathrm{AF}$ particle is a coarse crystal with microdomains, rather than an aggregate of crystallites. The $\mathrm{C}_{4} \mathrm{AF}$ particle size of approximately $2-4 \mu \mathrm{m}$ is comparable to the values observed for Portland cement clinker. ${ }^{29}$

$\mathrm{N}_{2}$ adsorption/desorption isotherms of the C-S-H and $\mathrm{C}_{4} \mathrm{AF}$ samples were measured (see Fig. 2a). The C-S-H sample showed a type-IV sorption behavior, with an H3-type hysteresis loop, which is characteristic of slit-like pores, giving rise to capillary condensation of the adsorbates. ${ }^{30,31}$ The BET specific surface area and average pore diameter were calculated to be $125 \mathrm{~m}^{2} \mathrm{~g}^{-1}$ and $19 \mathrm{~nm}$, respectively. The extent of $\mathrm{N}_{2}$ adsorption on the surface of the $\mathrm{C}_{4} \mathrm{AF}$ sample was significantly lower. Similarly, the adsorption volume obtained for this sample from the $\mathrm{Kr}$ sorption isotherm was smaller (see Fig. 2a), confirming that the surface area of $\mathrm{C}_{4} \mathrm{AF}$ available for gas adsorption was small. These results suggest that C-S-H is composed of aggregates of plate-like particles, while $\mathrm{C}_{4} \mathrm{AF}$ is a bulky, non-porous material. This agrees with the structural data obtained by XRD and TEM observations (Fig. 1).

The degrees of hydration of the C-S-H and $\mathrm{C}_{4} \mathrm{AF}$ samples were compared by thermal analysis (see Fig. 2b). The TGA curve for C$\mathrm{S}-\mathrm{H}$ indicated a weight loss of approximately $25 \%$ up to $600{ }^{\circ} \mathrm{C}$, 
(a)

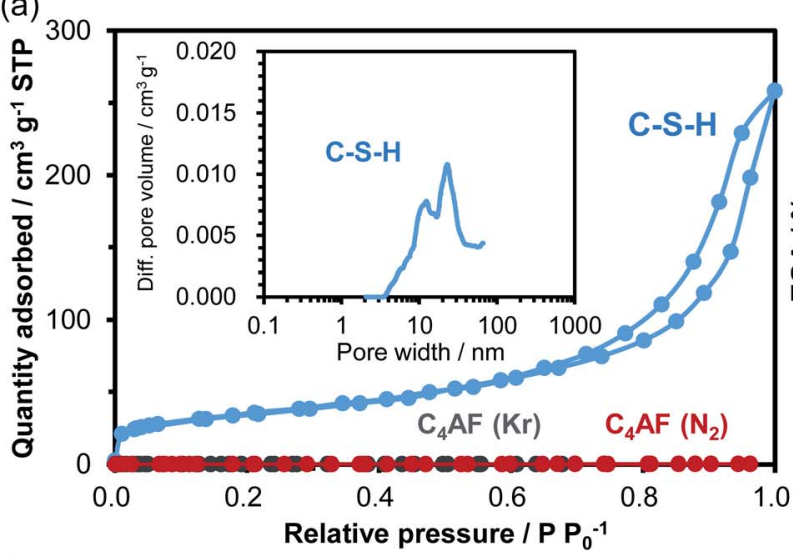

(c)

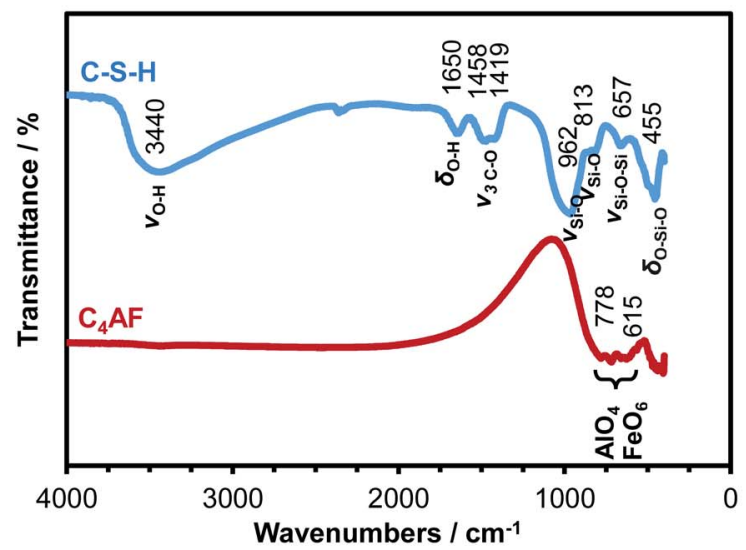

(b)

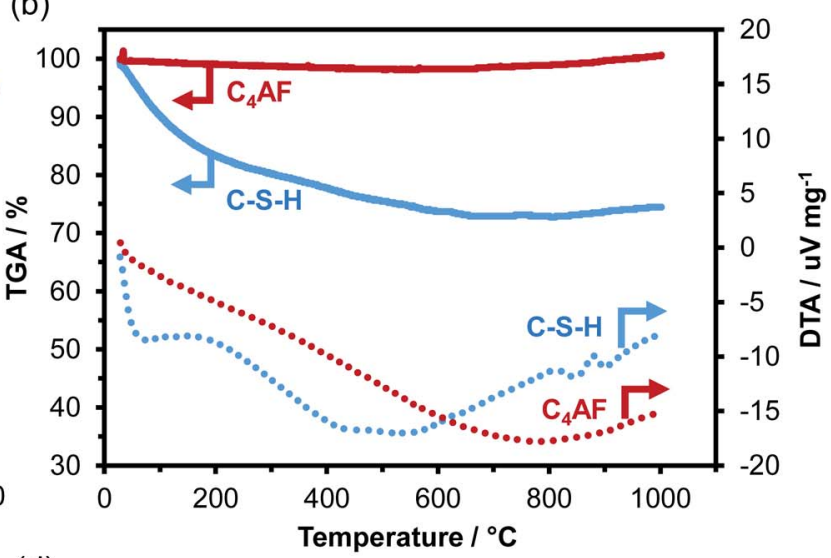

(d)

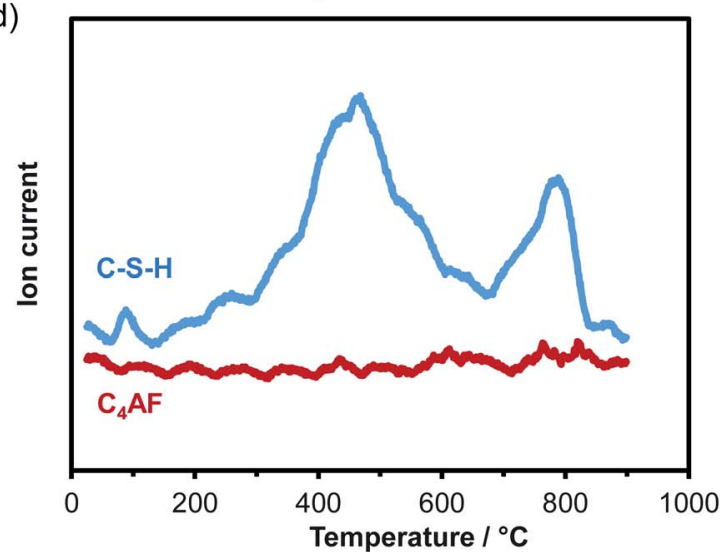

Fig. 2 (a) Adsorption/desorption isotherms of nitrogen for $\mathrm{C}-\mathrm{S}-\mathrm{H}$ and $\mathrm{C}_{4} \mathrm{AF}$ and of krypton for $\mathrm{C}_{4} \mathrm{AF}$. The inset is the pore size distribution of $\mathrm{C}$ $\mathrm{S}-\mathrm{H}$. (b) TG and DTA curves and (c) FTIR spectra of C-S-H and $\mathrm{C}_{4} \mathrm{AF}$. (d) Desorption profiles of $\mathrm{CO}_{2}$ for C-S-H and $\mathrm{C}_{4} \mathrm{AF}$.

while the DTA curve exhibited two endothermic peaks at $c a .70$ and $500{ }^{\circ} \mathrm{C}$, attributable to dehydration and dehydroxylation, respectively..$^{32,33}$ No weight loss was found above $600{ }^{\circ} \mathrm{C}$, which is indicative of the absence of $\mathrm{CaCO}_{3}$ in the C-S-H sample. In contrast, the weight of the $\mathrm{C}_{4} \mathrm{AF}$ sample remained almost unchanged during heating from room temperature to $1000{ }^{\circ} \mathrm{C}$, indicating that the as-synthesized sample was scarcely hydrated.

The results of FTIR analysis in Fig. 2c reveal the surface structures of the $\mathrm{C}-\mathrm{S}-\mathrm{H}$ and $\mathrm{C}_{4} \mathrm{AF}$ samples. The peak positions of all the bands observed for the C-S-H sample were in close agreement with the values reported by Lodeiro et $a .^{34}$ The broad and strong peak at $3440 \mathrm{~cm}^{-1}$ is assigned to the stretching vibration mode of $\mathrm{O}-\mathrm{H}$ groups. The peak at $1650 \mathrm{~cm}^{-1}$ is correlated to the bending vibration mode of $\mathrm{O}-\mathrm{H}$ groups. These peaks are attributed to the $\mathrm{O}-\mathrm{H}$ groups of both $\mathrm{C}-\mathrm{S}-\mathrm{H}$ and Ca-rich phase. The peaks of the carbonate group at 1458 and $1419 \mathrm{~cm}^{-1}$ correspond to the stretching vibrations of $\mathrm{C}-\mathrm{O}$ bond groups. The appearance of these peaks is attributed to the adsorption of atmospheric $\mathrm{CO}_{2}$ on the C-S-H surface occurring during the measurements. The four peaks at $1000-450 \mathrm{~cm}^{-1}$, typical of silicates, are ascribed to the asymmetric stretching vibration of $\mathrm{Si}-\mathrm{O}-\mathrm{Si}$ bonds for the first three peaks and to their bending vibration for the last peak. Meanwhile, the $\mathrm{C}_{4} \mathrm{AF}$ sample showed only two peaks at 778 and $615 \mathrm{~cm}^{-1}$ corresponding to internal modes of $\mathrm{AlO}_{4}$ tetrahedra and $\mathrm{FeO}_{6}$ octahedra in the brownmillerite structure,$^{35,36}$ which demonstrates the absence of any functional groups on the $\mathrm{C}_{4} \mathrm{AF}$ surface.

To gain further insight into the surface structure, TPD experiments were performed using $\mathrm{CO}_{2}$ as the probe molecule: the samples were loaded with $\mathrm{CO}_{2}$ at room temperature, followed by purging with $\mathrm{Ar}$ until no more $\mathrm{CO}_{2}$ desorption was detected. Afterwards, the temperature was increased linearly up to $900{ }^{\circ} \mathrm{C}$. In Fig. 2d, two large distinctive peaks are observed for the C-S-H sample, while no peak is found for the $\mathrm{C}_{4} \mathrm{AF}$ sample. This difference is due not only to the different specific surface areas of the two samples, but also to their relative basicities toward $\mathrm{CO}_{2}$. (The $\mathrm{pH}$ of a suspension of $0.2 \mathrm{~g}$ of C-S-H in $200 \mathrm{~mL}$ deionized water was found to be 11.9, which was higher than that of a suspension of $\mathrm{C}_{4} \mathrm{AF}$ in deionized water measured under the same conditions.) The FTIR analysis results indicate that $\mathrm{CO}_{2}$ is easily adsorbed on the C-S-H surface, but this adsorption likely does not occur on the inert $\mathrm{C}_{4} \mathrm{AF}$ surface. It is also apparent from the TPD results that C-S-H has at least two types of $\mathrm{O}-\mathrm{H}$ groups that vary in terms of basicity. This strongly suggests that the Ca-rich phase present in $\mathrm{C}-\mathrm{S}-\mathrm{H}$ has $\mathrm{O}-\mathrm{H}$ groups, which function as a second adsorption site for $\mathrm{CO}_{2}$.

\section{Electrical properties of C-S-H and $\mathrm{C}_{4} \mathrm{AF}$}

A $0.5 \mathrm{~mm}$-thick membrane composed of C-S-H or $\mathrm{C}_{4} \mathrm{AF}$ particles and PTFE binder was characterized through DC and AC 
conductivity measurements for each sample. An electrochemical cell containing the membrane electrolyte with $\mathrm{Pt} / \mathrm{C}$ electrodes was placed in flowing air saturated with water vapor at temperatures between 60 and $100{ }^{\circ} \mathrm{C}$. In the current interruption method, a current of 2 to $10 \mathrm{~mA} \mathrm{~cm} \mathrm{~cm}^{-1}$ was galvanostatically applied to the cell. When the current was interrupted, the cell voltage initially dropped rapidly and then decreased slowly with time (see inset in Fig. 3a). The initial voltage drop, corresponding to the product of the current $(I)$ and ohmic resistance $(R)$, was measured with various current densities at temperatures between 60 and $100^{\circ} \mathrm{C}$, and the results obtained for C-S-H are presented in Fig. 3 a as an example. At all the tested temperatures, the $I R$ drop and current density had an almost linear relationship, the slope of which was defined as the ohmic resistance. The $\mathrm{C}_{4} \mathrm{AF}$ membrane electrolyte also exhibited a linear relationship between the $I R$ drop and current density (data not shown). The DC conductivity can be calculated via

$$
\sigma=L /(R \times S)
$$

where $\sigma, L$, and $S$ are the conductivity $\left(\mathrm{S} \mathrm{cm}^{-1}\right)$, electrolyte thickness $(\mathrm{cm})$, and electrode area $\left(\mathrm{cm}^{2}\right)$, respectively. Fig. $3 \mathrm{~b}$ shows the temperature dependence of DC conductivity for C-S$\mathrm{H}$ and $\mathrm{C}_{4} \mathrm{AF}$ membranes over the $60-100{ }^{\circ} \mathrm{C}$ range. The conductivity for C-S-H was 4-9 times higher than that for $\mathrm{C}_{4} \mathrm{AF}$.
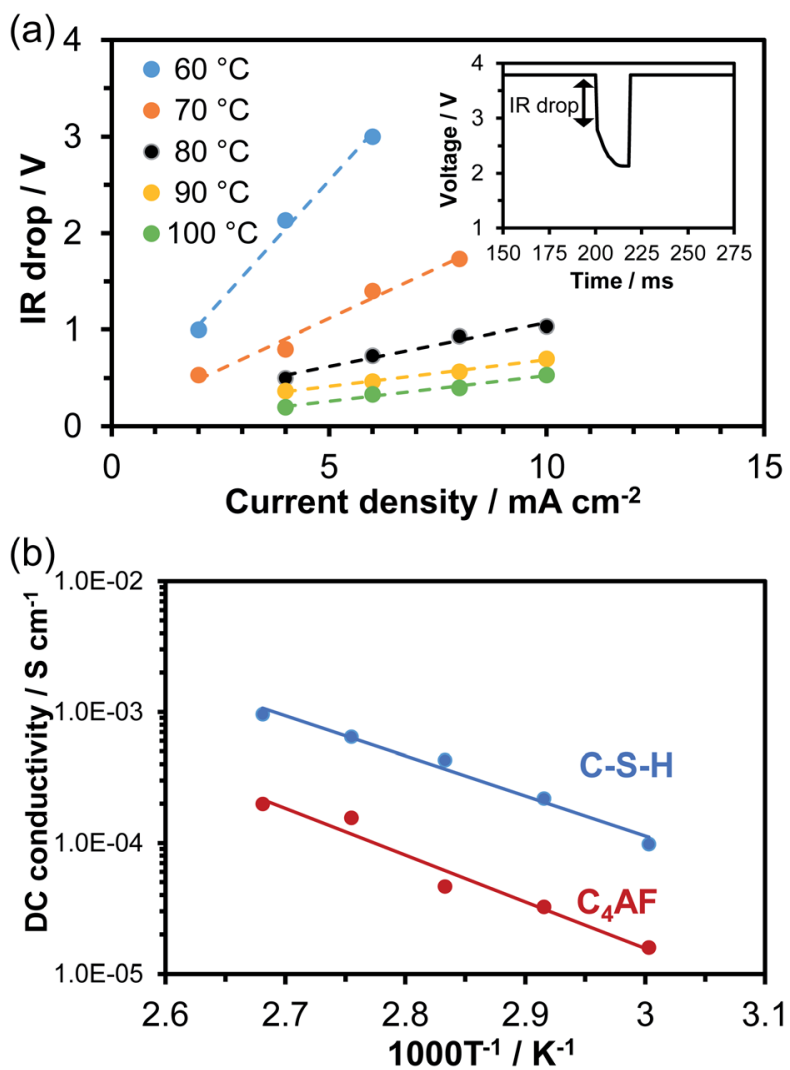

Fig. 3 (a) IR drop as a function of the current density recorded for $C$ $\mathrm{S}-\mathrm{H}$ at various temperatures. The inset is the transient change in voltage within a current interruption period. (b) Temperature dependence of DC conductivity for $\mathrm{C}-\mathrm{S}-\mathrm{H}$ and $\mathrm{C}_{4} \mathrm{AF}$.
Electrochemical impedance spectroscopy (EIS) is another powerful technique for measuring the ohmic resistance component of an electrolyte. The impedance spectra for cells using C-S-H and $\mathrm{C}_{4} \mathrm{AF}$ membrane electrolytes obtained at $60{ }^{\circ} \mathrm{C}$ are presented in Fig. 4a. At high frequencies, only the end section of the semicircle was observed for $\mathrm{C}-\mathrm{S}-\mathrm{H}$, while an almost complete semicircle was obtained for $\mathrm{C}_{4} \mathrm{AF}$. The highfrequency semicircle is often related to the ohmic resistance and the interfacial capacitance, rather than to the charge transfer resistance and the double layer capacitance, which will be discussed later. The ohmic resistance of the electrolyte was determined through equivalent circuit models, consisting of a resistor in parallel with a constant phase element (CPE) for C$\mathrm{S}-\mathrm{H}$ and a series resistor and a resistor-CPE parallel combination for $\mathrm{C}_{4} \mathrm{AF}$, both of which were accompanied by a Warburg impedance element. The ohmic resistance of $\mathrm{C}-\mathrm{S}-\mathrm{H}$ was computed to be $602 \Omega \mathrm{cm}^{-2}$, which is in agreement with the ohmic resistance of this membrane obtained by the current interruption method. Comparatively, the ohmic resistance of $\mathrm{C}_{4} \mathrm{AF}$ was resolved into bulk and interfacial contributions: a bulk resistance of $845 \Omega \mathrm{cm}^{-2}$ and an interfacial resistance of $1900 \Omega \mathrm{cm}^{-2}$. The sum of these values, $2745 \Omega \mathrm{cm}^{-2}$, is close to the DC ohmic resistance of this membrane. Thus, the semicircle observed at high frequencies is attributable to the interfacial resistance, presumably owing to the grain boundary contribution. It is also possible that this resistance is much

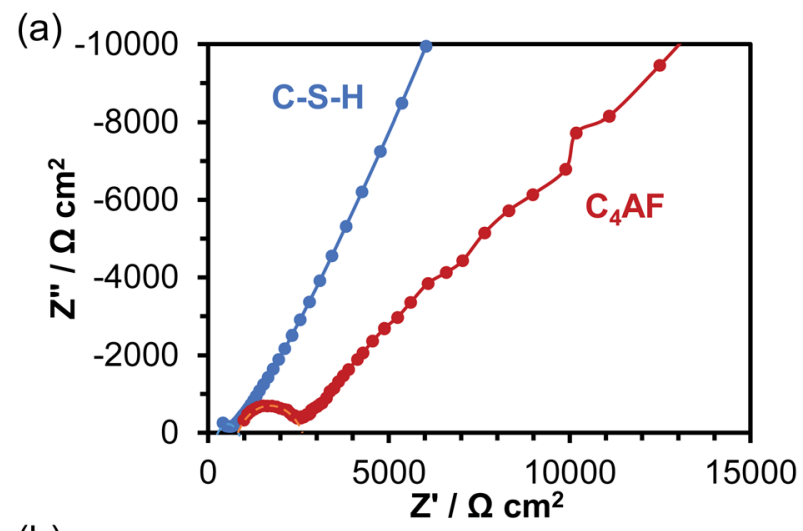

(b)

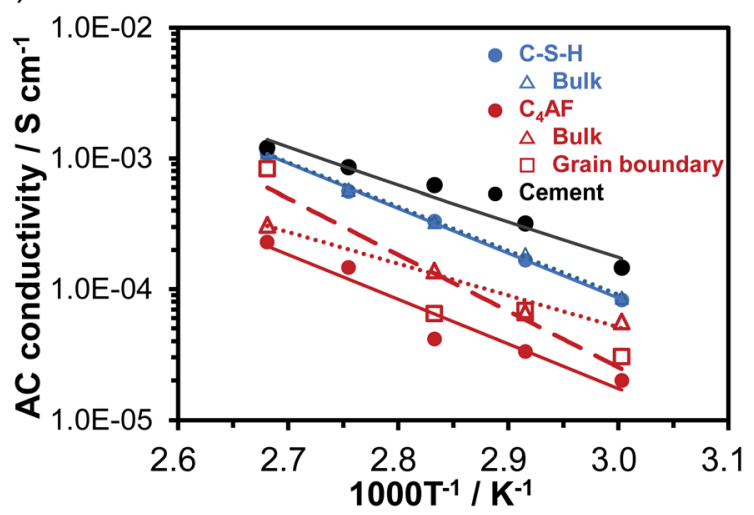

Fig. 4 (a) Impedance spectra of $\mathrm{C}-\mathrm{S}-\mathrm{H}$ and $\mathrm{C}_{4} \mathrm{AF}$ at $60^{\circ} \mathrm{C}$. (b) Temperature dependence of $\mathrm{AC}$ conductivity for $\mathrm{C}-\mathrm{S}-\mathrm{H}$ and $\mathrm{C}_{4} \mathrm{AF}$. 
smaller for C-S-H than for $\mathrm{C}_{4} \mathrm{AF}$, because C-S-H possesses a far higher specific surface area and a far larger amount of $\mathrm{O}-\mathrm{H}$ groups than $\mathrm{C}_{4} \mathrm{AF}$. Here, it should be noted that the Ca-rich phase was scattered on the C-S-H surface, as seen from the TEM image (see Fig. 1b). Thus, the Ca-rich phase does not contribute significantly to the reduction of the grain boundary resistance, due to a large gap between the phases. The ohmic resistances of these membranes above $60{ }^{\circ} \mathrm{C}$ were measured and estimated by similar procedures, and the AC conductivities were calculated via eqn (1). The results are presented in Fig. 4b, all of which are in good agreement with the DC conductivities obtained under the same conditions. Accordingly, the higher sum of the bulk and grain boundary conductivity of C-S-H as compared to $\mathrm{C}_{4} \mathrm{AF}$ can be explained in terms of its lower grain boundary resistance. The ionic or electronic current generally passes through the grains and across the grain boundaries in polycrystalline materials (bulk conduction mechanism). ${ }^{37}$ However, recent studies suggest that ion carriers, especially protons, can migrate along the grain boundaries in nanomaterials, whose resistance is affected sensitively by the amount of adsorbed water, grain size, and porosity (interfacial conduction mechanism). ${ }^{38-40}$ Thus, these two paths for ion transport need to be considered on the basis of the conduction mechanism. In the impedance spectrum of $\mathrm{C}_{4} \mathrm{AF}$, the grain boundary resistance was higher than the bulk resistance, and these components appeared individually. On the other hand, the impedance spectrum of C-S-H showed a single semicircle with a smaller diameter. These results, along with the characterization of the two materials, suggest that carrier transport occurs by the bulk conduction mechanism in $\mathrm{C}_{4} \mathrm{AF}$ and the interfacial conduction mechanism in C-S-H.

Fig. 4b also includes the AC conductivity of the hydrated cement paste recorded in our previous study. ${ }^{\mathbf{1 1}} \mathrm{A}$ somewhat higher conductivity was obtained for the cement paste, with a slightly lower activation energy $(0.57 \mathrm{eV})$ than the values for C$\mathrm{S}-\mathrm{H}$. This difference occurs because cement paste contains alkali metal ions such as $\mathrm{Na}^{+}$and $\mathrm{K}^{+}$, which bond to the silanol groups ( $\mathrm{Si}-\mathrm{OH}$ ) present on the C-S-H surface. ${ }^{41}$ The effect of $\mathrm{K}^{+}$ ions on electrical conductivity will be further investigated in the next section.

\section{Ionic conduction in C-S-H}

The characterization results demonstrated that the structure and morphology of the synthesized C-S-H sample closely resembled those of the $\mathrm{C}-\mathrm{S}-\mathrm{H}$ formed in the hydrated cement paste. In addition, electrical measurements led to a new insight: that the $\mathrm{C}-\mathrm{S}-\mathrm{H}$ membrane had relatively high electrical conductivity. These findings prompted us to investigate ionic conduction in C-S-H. Fig. 5a plots the dependence of conductivity on $P_{\mathrm{O}_{2}}$ at $100{ }^{\circ} \mathrm{C}$. The conductivity was kept constant at $10^{-3} \mathrm{~S} \mathrm{~cm}^{-1}$ over the $P_{\mathrm{O}_{2}}$ range from 1 to $10^{-23} \mathrm{~atm}$, and exhibited no characteristics of $\mathrm{p}$ - or n-type electronic conductivity. Clearly, C-S-H is a pure ionic conductor under both oxidizing and reducing atmospheres. Ionic conduction in $\mathrm{C}-\mathrm{S}-\mathrm{H}$ was further investigated by fabricating two galvanic cells using the membrane as the electrolyte: wet air|electrolyte|dry air; wet
$\mathrm{H}_{2}\left(P_{\mathrm{O}_{2}}=10^{-23}\right.$ atm $) \mid$ electrolyte $\mid$ wet $\operatorname{air}\left(P_{\mathrm{O}_{2}}=0.21\right.$ atm $)$. Fig. $5 \mathrm{~b}$ plots the electromotive force (EMF) values recorded between 50 and $100{ }^{\circ} \mathrm{C}$. The water vapor concentration cell always generated positive EMF values, which are defined as the potential of the electrode in wet air against the electrode in dry air. The $\mathrm{pH}$ value of the solution in equilibrium with C-S-H is reported to be in the range of $c a .10$ to $c a .12$, depending on the $\mathrm{Ca} / \mathrm{Si}$ molar ratio of $\mathrm{C}$ $\mathrm{S}-\mathrm{H} .^{42,43}$ Assuming that hydroxide ions are the major charge carriers under such alkaline conditions, the following reaction is proposed for the wet air electrode: ${ }^{\mathbf{4 4}}$

$$
\mathrm{H}_{2} \mathrm{O}+1 / 2 \mathrm{O}_{2}+2 \mathrm{e}^{-} \rightarrow 2 \mathrm{OH}^{-}
$$

In the oxygen gas concentration cell, the $\mathrm{H}_{2}$ electrode showed opposite polarity potentials at all the tested temperatures, which can be explained through the following reaction in the hydroxide ion conductor: ${ }^{45,46}$

$$
\mathrm{H}_{2}+2 \mathrm{OH}^{-} \rightarrow 2 \mathrm{H}_{2} \mathrm{O}+2 \mathrm{e}^{-}
$$

A decrease in the EMF value with decreasing membrane thickness was observed in the oxygen gas concentration cell (Fig. 5b), which was due to gas leakage and the resultant fuel loss. Thus, the observed EMF values were lower than the theoretical values calculated by the Nernst equation, depending on the membrane state. To obtain more direct evidence of hydroxide ion conduction, water vapor electrolysis was performed using the C-S-H membrane electrolyte at $100{ }^{\circ} \mathrm{C}$. The galvanostatic electrolysis characteristics are presented in Fig. 5c, along with the voltage-time curve at each current density. $\mathrm{H}_{2}$ was confirmed to be produced at the cathode, indicating that the $\mathrm{H}_{2}$ evolution reaction proceeded as follows:

$$
2 \mathrm{H}_{2} \mathrm{O}+2 \mathrm{e}^{-} \rightarrow \mathrm{H}_{2}+2 \mathrm{OH}^{-}
$$

It was also confirmed that the amount of $\mathrm{H}_{2}$ formed roughly agreed with the theoretical values calculated by Faraday's law, strongly supporting hydroxide ion conduction in C-S-H. Nevertheless, degradation of $\mathrm{H}_{2}$ production was observed at a current density of $60 \mathrm{~mA} \mathrm{~cm}^{-2}$ in Fig. 5c. This was due to the application of high voltage to the cell (see inset in Fig. 5c), which may have caused decomposition of the electrolyte or corrosion of the electrode. Note that unlike the C-S-H formed in cement pastes, the C-S-H examined in this study does not contain any alkaline metal ions, thus ruling out these ions as charge carriers. However, the contribution of $\mathrm{Ca}^{2+}$ ions released from the $\mathrm{Ca}$ rich phase to ionic conduction cannot be neglected.

From a practical standpoint, it is also important to determine the ionic conduction in C-S-H under alkaline conditions, because hydrated cement pastes contain alkaline metal ions. ${ }^{47,48}$ The impedance spectra of the C-S-H membrane were measured by adding $\mathrm{KOH}$ solutions with various $\mathrm{pH}$ values to the cell at $100{ }^{\circ} \mathrm{C}$. The results are presented in Fig. 5d. All impedance spectra consisted of three components in series: ohmic resistance (intercept of the impedance line and real axis), grain boundary resistance (high-frequency part of arc), and electrode reaction resistance (low-frequency part of inclined line). Both 

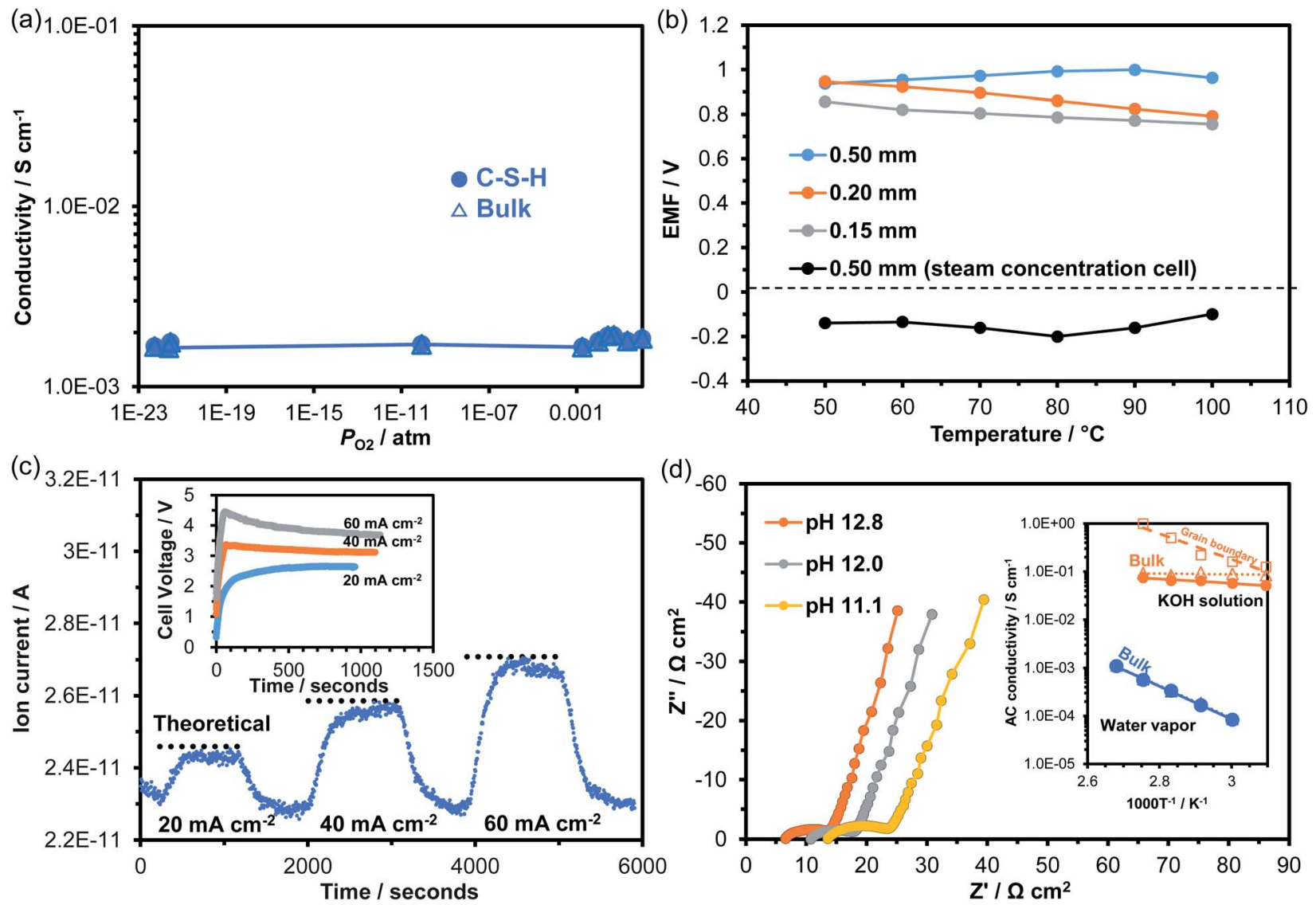

Fig. 5 (a) Dependence of conductivity of C-S-H on partial pressure of oxygen at $100{ }^{\circ} \mathrm{C}$. (b) EMF values obtained from the water vapor concentration cell and oxygen gas concentration cell at various temperatures. The working electrode is supplied with a flow of wet air or hydrogen. (c) Hydrogen quantity and voltage-time curves recorded during continuous electrolysis of water vapor with various current densities at $100^{\circ} \mathrm{C}$. (d) Impedance spectra of $\mathrm{C}-\mathrm{S}-\mathrm{H}$ operated in a $\mathrm{KOH}$ solution at varying $\mathrm{pH}$ at $100{ }^{\circ} \mathrm{C}$. The inset is the temperature dependence of conductivity for $\mathrm{C}-\mathrm{S}-\mathrm{H}$ operated in the $\mathrm{KOH}$ solution and in water vapor.

the ohmic and grain boundary resistances decreased with increasing $\mathrm{pH}$. These behaviors differ from those observed in the impedance spectrum for the alkaline-metal-free C-S-H membrane (see Fig. 4a). The difference is further emphasized by the much lower activation energy for ionic conduction ( $c a$. $0.1 \mathrm{eV}$ ) estimated for the C-S-H membrane operated at a $\mathrm{pH}$ of 12.8 , as compared to that operated in humidified air (see inset of Fig. 5d). This was due to the replacement of adsorbed water with $\mathrm{KOH}$ solution for the ion channels, which changes the interfacial conduction mechanism to vehicular diffusion or the Grotthuss mechanism for ionic conduction. ${ }^{37}$

These results demonstrated hydroxide ion conduction in C$\mathrm{S}-\mathrm{H}$, which is useful for interpreting the electrochemical behavior of hydrated cement pastes. Given its relatively high ion conductivity, C-S-H can function as an electrolyte for a variety of galvanic cells formed at the cement-steel interface in reinforced concrete structures, resulting in corrosion of the steel due to self-discharge when a local cell is established. In this case, the corrosion rate is directly affected by the humidity and basicity at the cement-steel interface. Importantly, such a local cell is formed even in the absence of alkali metal and alkaline earth metal hydroxides in the cement paste. Also important is the mesoporous structure formed in C-S-H, which enhances the water adsorption capacity of this material through capillary condensation. Thus, the hydroxide ion conductivity of C-S-H is maintained high even under low relative humidity conditions, which is one of the causes of increased corrosion under such conditions.

\section{Photoactive properties of $\mathrm{C}_{4} \mathrm{AF}$}

Although Fe-based photocatalysts have been studied extensively for their visible light response, ${ }^{12-14}$ there is no report on the photocatalytic activity of $\mathrm{C}_{4} \mathrm{AF}$ in the literature. Fig. 6a plots the dependence of $\mathrm{C}_{4} \mathrm{AF}$ membrane conductivity on $P_{\mathrm{O}_{2}}$ at $100{ }^{\circ} \mathrm{C}$. $\mathrm{C}_{4} \mathrm{AF}$ conductivity showed a negative correlation with $P_{\mathrm{O}_{2}}$ at high $P_{\mathrm{O}_{2}}$, indicating n-type electronic conductivity, but was independent of $P_{\mathrm{O}_{2}}$ at $P_{\mathrm{O}_{2}}$ values below 0.001 atm, suggesting that here, ion conductivity predominated. Thus, $\mathrm{C}_{4} \mathrm{AF}$ is identified as a mixed electronic and ionic conductor under oxidizing conditions. As described in the previous section, the bulk conduction was predominant in electrical conduction in $\mathrm{C}_{4} \mathrm{AF}$. In addition, brownmillerite-type oxides possess a large number of oxygen vacancies, which potentially introduces various ionic and electronic defects not only to the surface, but also into the 

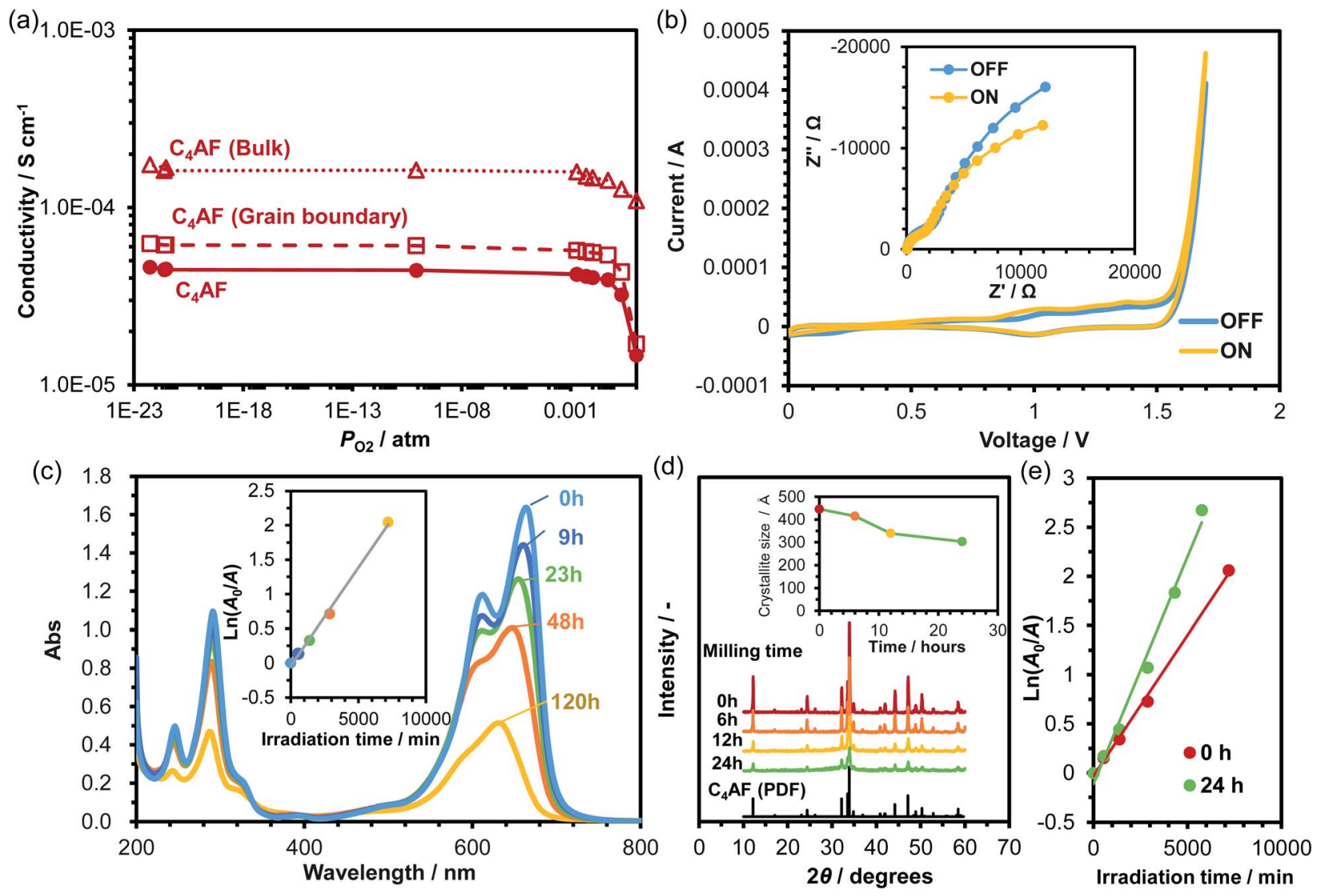

Fig. 6 (a) Dependence of conductivity of $C_{4} A F$ on the partial pressure of oxygen at $100{ }^{\circ} \mathrm{C}$. (b) $\mathrm{CV}$ curves for a water electrolysis cell with $\mathrm{C}_{4} \mathrm{AF}$ working electrode, Pt counter electrode, and $\mathrm{NaOH}$ solution electrolyte. The inset is the impedance spectra of the cell with and without irradiation. (c) Absorption spectra of MB during photocatalytic degradation under irradiation. The inset shows the natural logarithm of the relative absorbance $A_{0} / A$ against irradiation time. (d) XRD patterns and average crystallite size for milled $C_{4} A F$. (e) Plots of the natural logarithm of the relative absorbance $A_{0} / A$ of $M B$ against irradiation time for unground and ground $C_{4} A F$.

bulk of the oxides. ${ }^{49,50}$ The species and concentration of the ions introduced strongly depend on factors such as temperature, oxygen and water vapor partial pressures, and microstructure. ${ }^{\mathbf{4 0}}$ Thus, one cannot at present determine which ions function as charge carriers; however, alkaline metal ions can be ruled out, as in the case of the C-S-H membrane.

The electrode characteristics of $\mathrm{C}_{4} \mathrm{AF}$ as a photoanode were first validated by experimental demonstration of photovoltaic water splitting in a two-electrode cell consisting of a $\mathrm{C}_{4} \mathrm{AF}$ membrane anode, a Pt cathode, and a $\mathrm{NaOH}$ solution electrolyte. The CV profiles for this cell obtained under light and in the dark are presented in Fig. 6b, along with the corresponding impedance spectra recorded at a bias voltage of $+1 \mathrm{~V}$. Irradiation-induced enhancement effects were observed in both the cyclic voltammograms and impedance spectra, which are attributable to the decrease in the charge-transfer resistance due to irradiation. (In the impedance spectra, both the ohmic and grain boundary resistances were almost unchanged, regardless of the irradiation.) Next, the photocatalytic activity of $\mathrm{C}_{4} \mathrm{AF}$ was determined by degrading $\mathrm{MB}$ in deionized water under irradiation. The change in the absorbance of MB with irradiation time is shown in Fig. 6c. The peaks in the 600$700 \mathrm{~nm}$ range, which correspond to the conjugated $\pi$-system, and the peak at $291 \mathrm{~nm}$, assignable to the aromatic ring, decreased with time. Also, the color of the MB solution changed to light purple after irradiation for $120 \mathrm{~h}$. These results indicate that $\mathrm{C}_{4} \mathrm{AF}$ shows photocatalytic activity for the degradation of MB. From a plot of the natural logarithm of the relative absorbance $A_{0} / A$ against irradiation time (see inset of Fig. 6c), the first-order rate constant was calculated to be $3 \times 10^{-4} \mathrm{~min}^{-1}$, which is comparable to that of $\alpha-\mathrm{Fe}_{2} \mathrm{O}_{3}\left(3 \times 10^{-4} \mathrm{~min}^{-1}\right)$ and about half that of brownmillerite $\mathrm{Ca}_{2} \mathrm{Fe}_{2} \mathrm{O}_{5}\left(7 \times 10^{-4} \mathrm{~min}^{-1}\right) \cdot{ }^{14}$ Note that the specific surface area of $\mathrm{C}_{4} \mathrm{AF}$ was $0.8 \mathrm{~m}^{2} \mathrm{~g}^{-1}$, which is lower than those of $\mathrm{Fe}_{2} \mathrm{O}_{3}\left(5.9 \mathrm{~m}^{2} \mathrm{~g}^{-1}\right)$ and $\mathrm{Ca}_{2} \mathrm{Fe}_{2} \mathrm{O}_{5}\left(1.8 \mathrm{~m}^{2}\right.$ $\left.\mathrm{g}^{-1}\right)$. We cannot further compare the photocatalytic activities of different materials, since only the rate constant and BET specific surface area have been reported in the literature. Thus, an attempt was made to increase the specific surface area of $\mathrm{C}_{4} \mathrm{AF}$ by ball milling. The particle size of $\mathrm{C}_{4} \mathrm{AF}$ decreased with grinding time, as characterized by the decrease in the XRD peak intensity and in the average crystallite size (Fig. 6d). After a $24 \mathrm{~h}$ grinding run, the specific surface area of $\mathrm{C}_{4} \mathrm{AF}$ increased to 2.7 $\mathrm{m}^{2} \mathrm{~g}^{-1}$. (No additional effect on the specific surface area was observed past $24 \mathrm{~h}$.) Fig. 6e compares the rate constants for $\mathrm{MB}$ degradation in the case of unground and ground $\mathrm{C}_{4} \mathrm{AF}$. The rate constant estimated for ground $\mathrm{C}_{4} \mathrm{AF}$ was $5 \times 10^{-4} \mathrm{~min}^{-1}$, which 
is higher than that of $\mathrm{Fe}_{2} \mathrm{O}_{3}$, but lower than that of $\mathrm{Ca}_{2} \mathrm{Fe}_{2} \mathrm{O}_{5}$, despite the larger surface area of $\mathrm{C}_{4} \mathrm{AF}$. One possible reason for the difference in photoactivity between $\mathrm{C}_{4} \mathrm{AF}$ and $\mathrm{Ca}_{2} \mathrm{Fe}_{2} \mathrm{O}_{5}$ is the occupation of the tetrahedral sites of the brownmillerite structure by $\mathrm{Al}^{3+}$ ions, which may reduce the changeable valence state of $\mathrm{Fe}^{3+}$ ions in the octahedral sites. ${ }^{51}$

The occurrence of the photocatalytic reaction on the $\mathrm{C}_{4} \mathrm{AF}$ surface is not negligible in cement clinkers, but extremely rare in cement pastes, because portions of $\mathrm{C}_{4} \mathrm{AF}$ react with gypsum $\left(\mathrm{CaSO}_{4}\right)$ to form ettringite $\left[\mathrm{Ca}_{6}(\mathrm{Al}, \mathrm{Fe})\left(\mathrm{SO}_{4}\right)_{3} \cdot 26 \mathrm{H}_{2} \mathrm{O}\right] \cdot{ }^{52}$ However, if $\mathrm{C}_{4} \mathrm{AF}$ photocatalysis is actively applied to the removal of soil and pollutants from concrete surfaces, then it is required to increase the $\mathrm{C}_{4} \mathrm{AF}$ content of the cement clinker so as to form katoite $\left[\mathrm{Ca}_{3}(\mathrm{Al}, \mathrm{Fe})_{2}(\mathrm{OH})_{12}\right],{ }^{52}$ which has a higher potential as a photocatalyst than ettringite, because the present XRD results showed the coexistence of the brownmillerite and hydrogarnet (katoite) phases in the photoactive sample during MB photodegradation measurements (data not shown). If realized, this may eliminate the need to coat concrete surfaces with a photocatalyst such as $\mathrm{TiO}_{2}$ for self-cleaning purposes.

\section{Conclusions}

C-S- $\mathrm{H}$ and $\mathrm{C}_{4} \mathrm{AF}$ were prepared, characterized, and assessed in terms of ionic conductive and photocatalytic characteristics, respectively. C-S-H was composed of aggregates of plate-like particles with a high specific surface area and a large concentration of basic $\mathrm{O}-\mathrm{H}$ groups on their surface. Meanwhile, $\mathrm{C}_{4} \mathrm{AF}$ was a bulky non-porous material with a brownmillerite structure. C-S-H and $\mathrm{C}_{4} \mathrm{AF}$ showed different electrical properties at temperatures between 60 and $100{ }^{\circ} \mathrm{C}$ : bulk resistance was dominant in the total electrical resistance of C-S-H; grain boundary resistance contributed significantly to the total electrical resistance of $\mathrm{C}_{4} \mathrm{AF}$, especially at low temperatures. Consequently, the electrical conductivity of C-S-H was much higher than that of $\mathrm{C}_{4} \mathrm{AF}$. C-S-H was a pure ion conductor in the $P_{\mathrm{O}_{2}}$ range of $10^{-23}$ to $1 \mathrm{~atm}$, where ionic conduction occurs by the migration of hydroxide ions. The ion conductivity was determined to be $10^{-4} \mathrm{~S} \mathrm{~cm}^{-1}$ at $60{ }^{\circ} \mathrm{C}$ and $10^{-3} \mathrm{~S} \mathrm{~cm}^{-1}$ at $100{ }^{\circ} \mathrm{C}$, which are high enough to run gas concentration cells. $\mathrm{C}_{4} \mathrm{AF}$ was a mixed ionic and n-type electronic conductor at high $P_{\mathrm{O}_{2}}$. The $\mathrm{Fe}^{3+}$ ions in the octahedra induced photoanodic and photocatalytic activity for the water oxidation reaction and $\mathrm{MB}$ degradation, respectively. The ion conductivity of C-S-H and the photocatalytic activity of $\mathrm{C}_{4} \mathrm{AF}$ would contribute to the stability of concrete structures and the functionality of concrete surfaces.

\section{Conflicts of interest}

The authors declare no conflict of interest.

\section{Acknowledgements}

This research was funded by a Kakenhi Grant-in-Aid (No. 17H01895) from the Japan Society for the Promotion of Science (JSPS), and by a grant (No. JPMJCR18R2) from the CREST
Program of the Japan Science and Technology Agency (JST). The authors would like to thank Prof. Hikaru Nakamura (Nagoya University) for his inspiration.

\section{References}

1 P. C. Aïtcin, High performance concrete, CRC Press, 1998.

2 M. Stefanoni, U. Angst and B. Elsener, Cem. Concr. Res., 2018, 103, 35-48.

3 P. K. Mehta, ACI Symp. Publ., 1980, vol. 65, pp. 1-20.

4 R. J. Flatt, N. Roussel and C. R. Cheeseman, J. Eur. Ceram. Soc., 2012, 32, 2787-2798.

5 C. Medina, I. F. Sáez del Bosque, E. Asensio, M. Frías and M. I. Sánchez de Rojas, Mater. Struct., 2016, 49, 4595-4607.

6 R. Yu, P. Spiesz and H. J. H. Brouwers, Cem. Concr. Compos., 2015, 55, 383-394.

7 M. Castellote, L. Fernandez, C. Andrade and C. Alonso, Mater. Struct., 2009, 42, 515-525.

8 D. C. MacLaren and M. A. White, J. Chem. Educ., 2003, 80, 623-635.

9 M. M. Hassan, H. Dylla, L. N. Mohammad and T. Rupnow, Constr. Build. Mater., 2010, 24, 1456-1461.

10 A. Folli, I. Pochard, A. Nonat, U. H. Jakobsen, A. M. Shepherd and D. E. Macphee, J. Am. Ceram. Soc., 2010, 93, 3360-3369.

11 M. Nagao, K. Kobayashi, T. Hori, Y. Li and T. Hibino, Materials, 2019, 12, 3701.

12 S. Kumar, S. Tonda, B. Kumar, A. Baruah and V. Shanker, J. Phys. Chem. C, 2013, 117, 26135-26143.

13 K. Shetty, L. Renuka, H. P. Nagaswarupa, H. Nagabhushana, K. S. Anantharaju, D. Rangappa, S. C. Prashantha and K. Ashwini, Mater. Today: Proc., 2017, 4, 11806-11815.

14 J. Ikawa, S. Komai, D. Hirabayashi, F. Ya'ning, M. Lei and K. Suzuki, Proc. Int. Symp. EcoTopia Sci. 2007, 2007, vol. 7, pp. 959-964.

15 A. Cuesta, I. Santacruz, S. G. Sanfélix, F. Fauth, M. A. G. Aranda and A. G. De La Torre, Constr. Build. Mater., 2015, 101, 818-827.

16 X. Huang, S. Hu, F. Wang, L. Yang, M. Rao and Y. Tao, ACS Sustainable Chem. Eng., 2019, 7, 6792-6801.

17 B. Z. Dilnesa, B. Lothenbach, E. Wieland, R. Dähn, A. Wichser and K. L. Scrivener, Conmod 2010, Rilem, Bagneux, 2010.

18 B. Z. Dilnesa, E. Wieland, B. Lothenbach, R. Dähn and K. L. Scrivener, Cem. Concr. Res., 2014, 58, 45-55.

19 I. Maruyama and G. Igarashi, J. Adv. Concr. Technol., 2014, 12, 200-213.

20 A. Hajimohammadi, T. Ngo, P. Mendis, A. Kashani and J. S. J. van Deventer, J. Cleaner Prod., 2017, 147, 330-339.

21 S. M. Park and J. G. Jang, J. Nucl. Mater., 2018, 505, 159-164. 22 I. G. Richardson, Cem. Concr. Res., 2008, 38, 137-158.

23 I. G. Richardson, Acta Crystallogr., Sect. B: Struct. Sci., Cryst. Eng. Mater., 2014, B70, 903-923.

24 I. G. Richardson, Cem. Concr. Res., 2004, 34, 1733-1777. 25 H. D. Megaw and C. H. Kelsey, Nature, 1956, 177, 390-391. 26 I. G. Richardson, Cem. Concr. Res., 1999, 29, 1131-1147.

27 I. G. Richardson, J. Skibsted, L. Black and R. J. Kirkpatrick, Adv. Cem. Res., 2010, 22, 233-248. 
28 N. Meller, C. Hall and J. S. Phipps, Mater. Res. Bull., 2005, 40, 715-723.

29 A. Crumbie, G. Walenta and T. Füllmann, Cem. Concr. Res., 2006, 36, 1542-1547.

30 W. Gac, A. Patrykiejew and S. Sokołowski, Thin Solid Films, 1997, 298, 22-32.

31 T. Horikawa, D. D. Do and D. Nicholson, Adv. Colloid Interface Sci., 2011, 169, 40-58.

32 B. El-Jazairi and J. M. Illston, Cem. Concr. Res., 1977, 7, 247257.

33 J. I. Bhatty, Thermochim. Acta, 1986, 106, 93-103.

34 I. García Lodeiro, A. Fernández-Jimenez, A. Palomo and D. E. Macphee, Cem. Concr. Res., 2010, 40, 27-32.

35 I. J. Moraes, M. C. Terrile, O. R. Nascimento, M. S. Li, R. H. P. Francisco and J. R. Lechat, Mater. Res. Bull., 1992, 27, 523-529.

36 T. Nishida, S. Kubuki, M. Shibata, Y. Maeda and T. Tamaki, J. Mater. Chem., 1997, 7, 1801-1806.

37 K. D. Kreuer, Annu. Rev. Mater. Res., 2003, 33, 333-359.

38 S. Kim, H. J. Avila-Paredes, S. Wang, C. T. Chen, R. A. Souza, M. Martin and Z. A. Munir, Phys. Chem. Chem. Phys., 2009, 11, 3035-3038.

39 S. Miyoshi, Y. Akao, N. Kuwata, J. Kawamura, Y. Oyama, T. Yagi and S. Yamaguchi, Chem. Mater., 2014, 26, 51945200 .
40 Y. Meng, J. Gao, Z. Zhao, J. Amoroso, J. Tong and K. S. Brinkman, J. Mater. Sci., 2019, 54, 9291-9312.

41 S.-Y. Hong and F. P. Glasser, Cem. Concr. Res., 1999, 29, 1893-1903.

42 G. M. N. Baston, A. P. Clacher, T. G. Heath, F. M. I. Hunter, V. Smith and S. W. Swanton, Mineral. Mag., 2012, 76, 30453053.

43 B. Lothenbach and A. Nonat, Cem. Concr. Res., 2015, 78, 5770.

44 K. Tadanaga, Y. Furukawa, A. Hayashi and M. Tatsumisago, Adv. Mater., 2010, 22, 4401-4404.

45 G. Merle, M. Wessling and K. Nijmeijer, J. Membr. Sci., 2011, 377, 1-35.

46 Z. F. Pan, L. An, T. S. Zhao and Z. K. Tang, Prog. Energy Combust. Sci., 2018, 66, 141-175.

47 B. Šavija and M. Luković, Constr. Build. Mater., 2016, 117, 285-301.

48 S. O. Ekolu, Constr. Build. Mater., 2016, 127, 306-320.

49 C. P. Jijil, S. M. Unni, K. Sreekumar and R. N. Devi, Chem. Mater., 2012, 24, 2823-2828.

50 C. P. Jijil, S. N. Bhange, S. Kurungot and R. N. Devi, ACS Appl. Mater. Interfaces, 2015, 7, 3041-3049.

51 Y. Yang, Z. Cao, Y. Jiang, L. Liu and Y. Sun, Mater. Sci. Eng., B, 2006, 132, 311-314.

52 N. Meller, C. Hall, A. C. Jupe, S. L. Colston, S. D. M. Jacques, P. Barnes and J. Phipps, J. Mater. Chem., 2004, 14, 428-435. 